\title{
Protein recovery from residual bovine whey: Influence of acid thermo-coagulation
}

\author{
Victoria E. García Casas, Jeffrey Vargas Pérez², Roberto Sánchez Companioni³ Nardy Diez García²
}

DOl. 10.21931/RB/2021.06.01.24

\begin{abstract}
Thermal treatment of acidified bovine whey is one of the most efficient traditional methods for the recovery and use of residual proteins in this byproduct and an alternative way of sustainable use of this type of resource. The yield of protein recovery from residual whey obtained as a byproduct was evaluated using the acid thermo-coagulation method. Bovine whey samples were collected in dry and rainy seasons and were subjected to acid thermo-coagulation, and the protein sample preparation was achieved using the TCA/Acetone and TCA/Acetone/Phenol methods. The determination of peptides was accomplished by electrophoresis SDS-PAGE. The TCA/Acetone/Phenol method reported better performance with a higher yield $(22.2 \mu \mathrm{g} / \mathrm{ml})$ than the classic TCA/ Acetone method $(8.8 \mu \mathrm{g} / \mathrm{ml})$. The proteins found in higher proportion in whey samples of the dry season, representing $82.6 \%$ of the total protein content, while in whey samples of rainy season equivalent up to $65.4 \%$ of total proteins. The acid thermo-coagulation technique showed high-efficiency performance in whey peptide recovery.
\end{abstract}

Key words: Electrophoresis, protein recovery, protein sample preparation, whey.

\section{Introduction}

Considering the accelerated demographic expansion in the planet, one of the most significant challenges is the conservation, improvement, and sustainable use of natural resources for food and agriculture, as said by the United Nations Food and Agriculture Organization (FAO). This common interest has promoted the endless search and development of new technologies that allow the optimization in the use of available resources, giving added value to byproducts of primary processes, reducing production costs, and mitigating the environmental impact ${ }^{1}$.

Whey is the liquid byproduct generated in cheese production; its recovery and use has been studied and is widely known ${ }^{2,3}$; nevertheless, in developing countries as Ecuador, the use of whey is still limited, restricted to animal feeding, and the unused residue is discharged to the environment without previous treatment ${ }^{4}$, as a contaminant of soils and waters. This work was carried out to determine the recovery yield of bovine whey proteins using acid thermo-coagulation. The acid thermo-coagulation was studied at three different temperatures; two protein sample methods were compared, TCA/Acetone and TCA/Acetone/Phenol, and the peptide profiles were evaluated from whey collected in dry and rainy seasons.

Lacto-serum has excellent importance from the nutritional point of view ${ }^{5}$, because it is rich in high biological value proteins $s^{4}$ and is a high nutritive value food ${ }^{6,7}$, with a high content of essential amino acids ${ }^{8,9}$

Bovine whey proteins contain a higher quantity of branched-chain amino acids (BCAA) and essential amino acids than other sources ${ }^{10,11}$. Whey is additionally an important source of bioactive peptides ${ }^{12}$ that are formed by the enzymatic process to which is subjected milk in cheese elaboration ${ }^{6,8,13}$; whey contents casein macro peptides produced by renin action that causes hydrolysis of $\mathrm{\kappa}$-casein ${ }^{14,15}$; besides, it contains minor quantities of lactoferrins, lactoperoxidases, and immunoglobulins among other proteins of interest for the pharmaceutical and food industries ${ }^{16}$. However, if these proteins' precipitation is desired, it is necessary to subject whey to temperatures higher than $70^{\circ} \mathrm{C}^{17,18}$.

Thermal treatment of acidified whey is the most ancient traditional procedure used to prepare cottage cheese to recover the proteins that the liquid byproduct contains. This procedure is also used to elaborate food products as spread creams and nutritional supplements in powder, developed from whey proteins $^{19}$, as an economical and efficient method ${ }^{6}$. The acid thermo-coagulation involves the change of protein structure, which generates interactions of polypeptide chains ${ }^{20}$; proteins lose their native structure because of noncovalent interactions, maintaining the structural stability.

The solubility of whey proteins depends on $\mathrm{pH}$, ionic force, and temperature. When $\mathrm{pH}$ is low, solubility decreases. $\beta$-lactoglobulin is approximately $90 \%$ soluble in its isoelectric point $(\mathrm{pl})^{21}$, while a-lactoalbumin is only $68 \%$ soluble. Temperature is the most critical variable affecting whey protein solubility 22 ; as temperature increases, protein molecules are denatured and change their tridimensional configuration; ionic and hydrogen bonds are broken, hydrophobic groups are exposed the attractive interactions with water are reduced when the process of denaturation of proteins is irreversible, the aggregation and precipitation occur ${ }^{23}$.

\section{Materials and methods}

\section{Sample collection and physicochemical analysis}

Whey samples were collected in the milk collection center and cheese industry Diprolac, located in canton Balzar, Guayas Province, Ecuador, as a byproduct from enzymatic coagulation of milk Brahman cattle. Samples were collected in dry and rainy seasons. Physicochemical analyses were done to determine protein content, carbohydrates, fat, ashes, total reliable content, acidity, and $\mathrm{pH}$, according to the Ecuadorian Technical Standard NTE INEN 2594:2011 defined by the Ecuadorian Standardization Institute ${ }^{24}$.

\section{Acid Thermo-coagulation}

The protein concentrate was obtained by acid thermo-coa-

${ }_{1}^{1}$ Facultad de Ingeniería Química, Universidad de Guayaquil, Guayaquil, Ecuador.

${ }^{2}$ Centro de Investigación Biotecnológicas del Ecuador (CIBE), Escuela Superior Politécnica del Litoral, ESPOL, Guayaquil, Ecuador.

${ }^{3}$ Instituto Superior Universitario de Formación, Guayaquil, Ecuador. 
gulation of sweet whey. Samples of $250 \mathrm{ml}$ were pasteurized at $65^{\circ} \mathrm{C}$ for 30 minutes; $\mathrm{pH}$ was adjusted to 6.51 and 4.6 using $50 \%$ citric acid (C6H8O7) solution. Three different heating treatments were made, adjusting temperature gradually to 65,75 , and $80{ }^{\circ} \mathrm{C}$, with constant stirring and heating periods of 20 minutes. When the final temperature was reached $\left(80^{\circ} \mathrm{C}\right)$, the whey was allowed to stay for 15 minutes and was filtered by gravity with a glass microfiber sheet Whatman grade GF/A, pore size $1.6 \mu \mathrm{m}$. During experimentation, whey and retentate samples were taken to evaluate the recovery efficiency and peptide profile at each temperature.

\section{Protein extraction and quantification}

Protein extraction was done from six whey samples subjected to three different thermal treatments $\left(65,75\right.$, and $\left.80{ }^{\circ} \mathrm{C}\right)$ by triplicate. The TCA/Acetone and TCA/Acetone/Phenol methods were used following Wang ${ }^{25}$ modified protocol. Yield recovery and protein concentration were determined by Bradford ${ }^{26}$ method.

\section{Peptide determination (SDS-PAGE Gel)}

SDS-PAGE separated proteins according to the method of Laemmli27. For this, $20 \mu \mathrm{g}$ of proteins were dissociated in the presence of denaturing buffer $(20 \mathrm{mM}$ Tris-HCl pH 8.6 containing 1\% SDS, $8.3 \%$ glycerol, and $0.5 \%$ 2-mercaptoethanol) and incubated at $90{ }^{\circ} \mathrm{C}$ for 5 min and separated by electrophoresis on $12 \%$ polyacrylamide gels.

Proteins were stained with Coomassie Brillant Blue and destained in $7 \%$ acetic acid. Finally, the gels obtained from electrophoresis were analyzed with Imagine Lab Software and the bands' number and intensity, and their molecular weights were determined.

\section{Data Analysis}

To observe differences between protein content in lacto-sera collected in dry and rainy seasons, t Student tests were used for two samples, previous Snedecor F test (Fisher-Snedecor distribution) for the determination of data homoscedasticity. Additionally, two factors ANOVA was done to observe differences in the peptide recovery with respect to the treatment stage (whey, $65^{\circ} \mathrm{C}, 75^{\circ} \mathrm{C}, 80^{\circ} \mathrm{C}$ and retentate) climatic season. The significance limit was stipulated to $2 \%$ (P $<0.02)$ for a confidence level of $98 \%$ in all the analyses. The analysis was made entirely with the Microsoft Excel version 2010 program.

\section{Results}

\section{Physicochemical analysis of whey}

The physicochemical analysis allowed to establish that protein content of whey collected in the dry season highly exceeds the protein content of rainy season whey, representing more than twice its value, while the total fat content is higher in the rainy season, as are ashes and carbohydrate content (Table 1)

\section{Contaminant removal by TCA/Acetone and TCA/Acetone/ Phenol protocols}

The contaminant removal with TCA/Acetone protocol showed a minimum variation in the protein recovery yield for all thermal treatments, while TCA/Acetone/Phenol protocol resulted in higher protein recovery yield with temperature increase. Concerning the final paste obtained with acid thermo-coagulation, it was reported a higher yield using TCA/Acetone/Phenol protocol $(22.6 \mu \mathrm{g} / \mathrm{ml})$ compared to TCA/Acetone $(8.8 \mu \mathrm{g} / \mathrm{ml})$ (Figure 1).

\section{SDS-PAGE TCA/Acetone - TCA/Acetone/Phenol}

When comparing SDS-PAGE results for the two protocols used in the protein sample preparation, more defined bands are appreciated for the low molecular weight peptides in the extract obtained by TCA/Acetone/Phenol (Figure 2).

Whey samples collected in dry and rainy seasons did not show relevant differences in the analysis of SDS-PAGE gels, except for lower molecular weight proteins $(<20 \mathrm{kDa})$, whose bands appear less abundant in dry season whey (Figure 3 left / lanes 2-6) compared to the same type of proteins in rainy season whey (Figure 3 right/lanes 7-11).

\section{Protein quantification in Lacto-sera collected in dry and rainy seasons}

Table 2 shows the peptide percent in samples of both climatic seasons; particularly for the dry season, it can be noticed that the paste contains peptides with non-normalized molecular weights of $12.06,15.43,17.01$, and $27.98 \mathrm{kDa}$, which represent $82.6 \%$ of the total peptide content in the original whey. On the other hand, the paste obtained from the rainy season showed peptide groups with non-normalized molecular weights of $11.86,16.51,17.57$ and $26.54 \mathrm{kDa}$ represent the 65.36 $\%$ of total peptide content in whey.

Concerning peptides observed in SDS-PAGE in dry and rainy seasons, it can be appreciated that those with molecular weights of $15.43 \mathrm{kDa}$ and $17.01 \mathrm{kDa}$ are found in higher concentration in dry season whey, compared to the peptides of similar molecular weights in rainy season whey. Samples of whey collected in the rainy season showed higher concentrations for the rest of the peptides, and there were no statistically significant differences between each peptide concentration in climatic seasons $(P>0.05)$, except for molecular weight peptides of $15.43 \mathrm{kDa}$ and $16.51 \mathrm{kDa}(\mathrm{t}=3.08 ; \mathrm{P}=0.015)$, being these in average, higher in the dry season (21.2 \%) than in rainy

\begin{tabular}{|c|c|c|c|c|c|}
\hline Essay & Unit & $\begin{array}{c}\text { Rainy } \\
\text { season }\end{array}$ & $\begin{array}{c}\text { Dry } \\
\text { season }\end{array}$ & $\begin{array}{c}\text { Standard } \\
\text { Deviation }\end{array}$ & Method Reference \\
\hline Acidity & $\%$ & 0.09 & 0.11 & 0.01 & NTE INEN 13 \\
\hline Carbohydrates by difference & $\%$ & 5.05 & 4.68 & 0.26 & Calculation \\
\hline Ashes & $\mathrm{m} / \mathrm{m}$ & 0.52 & 0.04 & 0.34 & NTE INEN 14:1983 \\
\hline Total fat & $\%$ & 1.2 & 0.6 & 0.42 & AOAC 19TH 989.05 \\
\hline $\mathrm{pH}$ & - & 6.15 & 6.51 & 0.25 & AOAC 19TH 973.41 \\
\hline Protein & $\%$ & 1.05 & 2.9 & 1.31 & $\begin{array}{c}\text { AOAC 19TH 991.20 } \\
\text { (API 5.8-04-01-00B24) }\end{array}$ \\
\hline Total solids & $\%$ & 7.85 & 7.68 & 0.12 & NTE INEN 14:1983 \\
\hline
\end{tabular}

Table 1. Physicochemical Analysis of residual whey from Diprolac dairy industry, canton Balzar, Ecuador. 


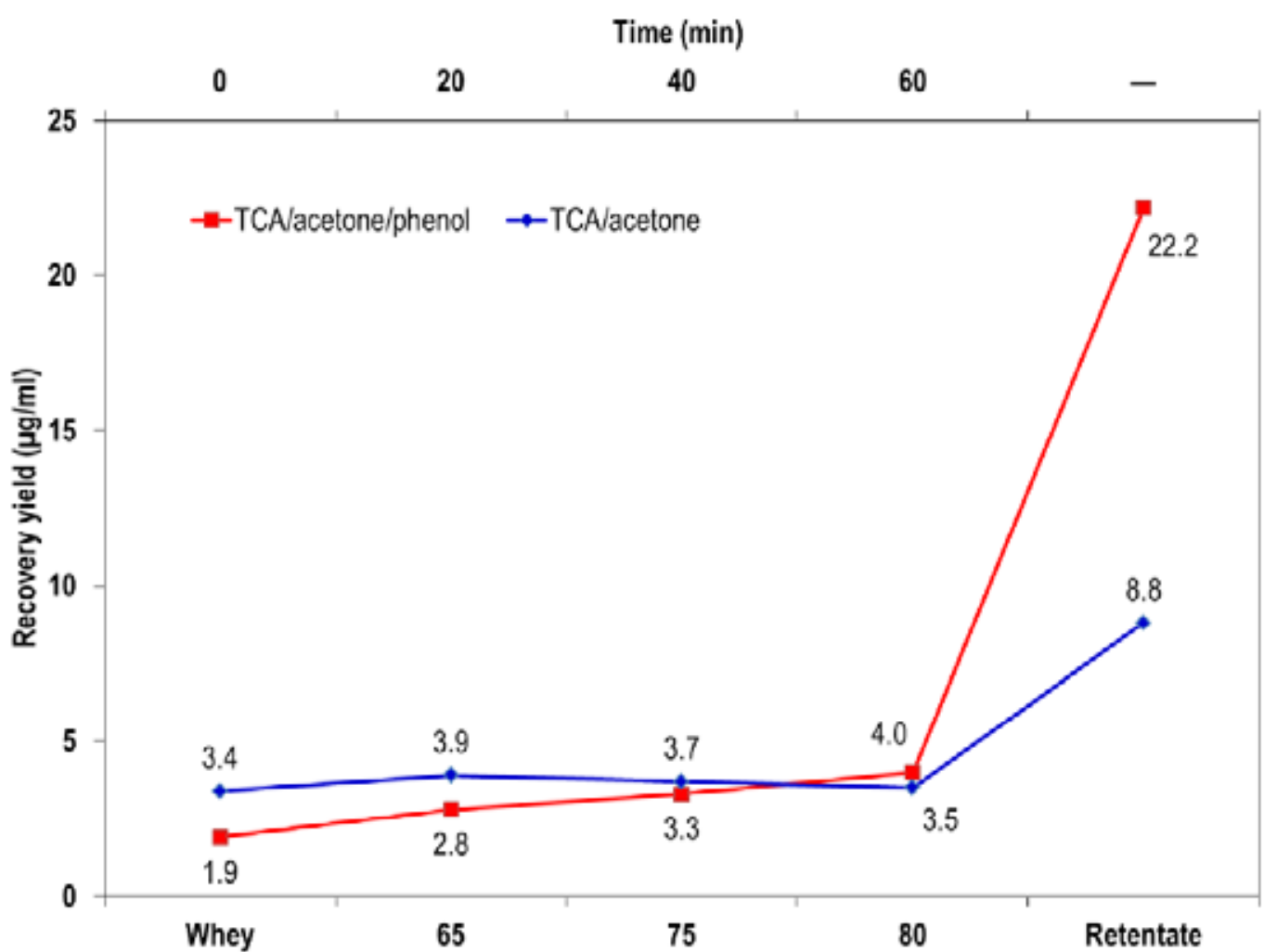

Figure 1. Yield of protein extraction protocols used in bovine whey.

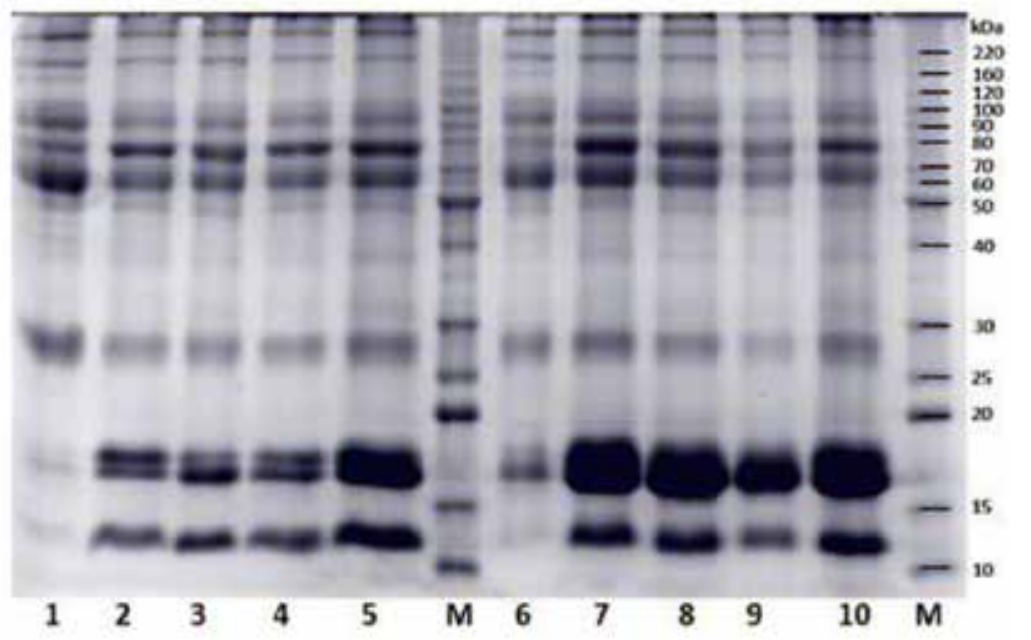

Figure 2. SDS-PAGE gels for each protein extraction protocol. Lanes 1-5, TCA/acetone/phenol; lane 1: whey; lane 2: $65^{\circ} \mathrm{C}$ treatment; lane 3: $75^{\circ} \mathrm{C}$ treatment; lane $4: 80^{\circ} \mathrm{C}$ treatment; lane 5: Paste; lanes 6-10 TCA/acetone; lane 6: whey; lane $7: 65^{\circ} \mathrm{C}$ treatment; lane $8: 75^{\circ} \mathrm{C}$ treatment; lane 9: 80 ㅇ $\mathrm{C}$ treatment; lane 10: Retentate; $\mathrm{M}$ : protein mass markers.
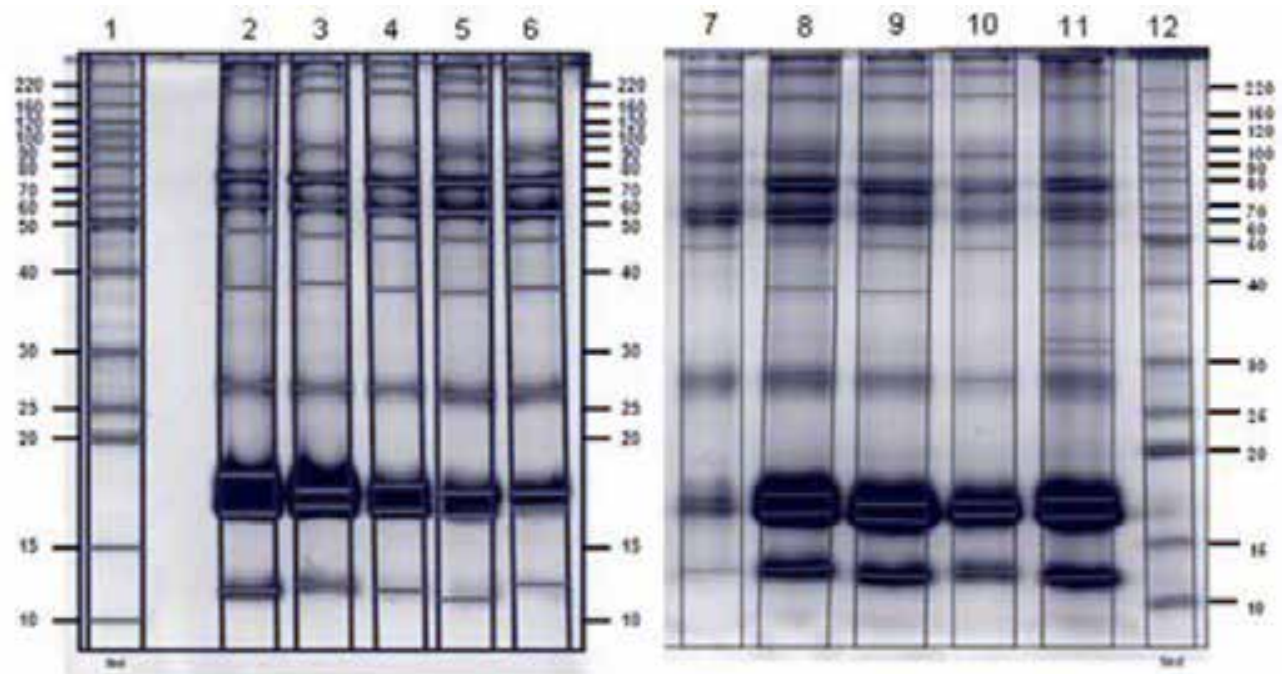

Figure 3. SDS-PAGE gel of dry season (left) and rainy season (right) wheys, using TCA/Acetone/Phenol protocol. 1: Molecular weight marker; 2: Paste; 3: $80{ }^{\circ} \mathrm{C}$ treatment; $4: 75{ }^{\circ} \mathrm{C}$ treatment; 5: $65{ }^{\circ} \mathrm{C}$ treatment; 6: Whey without treatment; 7: Whey without treatment; 8: $65^{\circ} \mathrm{C}$ treatment; $9: 75^{\circ} \mathrm{C}$ treatment; $10: 80^{\circ} \mathrm{C}$ treatment; 11: Paste; 12: Molecular weight marker. 
season (5.8\%). Likewise, peptides with molecular weights of $32.44 \mathrm{kDa}, 31.01 \mathrm{kDa}$, and $160.61 \mathrm{kDa}$ in dry season whey were evident, and these particular peptides were not detected in the rainy season whey (Table 2 ).

On the other hand, according to the ANOVA test, there are no significant differences in the recovery of proteins between the process stages ( $F=0.01 ; P=0.99$ ), nor between climatic seasons ( $F=0.04 ; P=0.99$ ). Nevertheless, acid thermo-coagulation allows the recovery of soluble proteins from whey with an increase in recovery efficiency, with the increase in temperature.

\section{Conclusions}

Characterization of residual whey from cheese industry Diprolac, canton Balzar, Ecuador, in dry and rainy seasons, shows punctual differences; for example, total carbohydrates and fat contents were higher in rainy season whey, while observed protein content was higher in the dry season. These type of differences are common because of changes in livestock feeding associated with climatic seasons ${ }^{28,29}$; other factors as bovine breed ${ }^{30}$ and cheese production technology ${ }^{31}$ can also affect characteristics and composition of whey.

The acid thermo-coagulation process studied in this work allowed us to establish that it is not necessary to reach tempe- ratures higher than $80{ }^{\circ} \mathrm{C}$ to achieve a higher protein recovery yield. That was more evident when evaluating results after the extraction with TCA/Acetone/Phenol protocol. As opposed to the results reported by Revilla ${ }^{32}$ and Vázquez Puente et $a L^{19}$, which indicate that the rise in denaturation temperature (DT) reports higher recovery yield of protein aggregate, the results obtained in this work showed that at $75^{\circ} \mathrm{C}$, stabilization and higher performance of the process is reached.

On the other hand, the acid thermo-coagulation method offers a higher retentate recovery, which is observed in band concentration in SDS-PAGE gels (Figure 2), where a higher peptide concentration in the bands of pastes is appreciated, compared to the bands of whey without treatment.

Paste recovery using TCA/Acetone/Phenol as extraction protocol was higher than treatment without Phenol. During TCA/Acetone/Phenol treatment, washes remove acetone soluble compounds (salts and other polar contaminants) and phenol soluble contaminants (lipids, carbohydrates, and phenolic compounds), obtaining; as a result, a cleaner, less contaminated product, which favors the acid precipitation of proteins $^{25}$. However, the SDS-PAGE observed results suggest that the contaminant removal protocol does not affect the band pattern.

The paste obtained from dry season whey showed peptides between 12 and 28 kDa, representing $82.6 \%$ of total

\begin{tabular}{|c|c|c|c|c|c|c|c|}
\hline Climatic Season & $\begin{array}{c}\text { Molecular weight } \\
\text { (kDa) }\end{array}$ & $\begin{array}{c}\text { Whey } \\
(\%)\end{array}$ & $\begin{array}{l}65^{\circ} \\
(\%)\end{array}$ & $\begin{array}{l}75^{\circ} \\
(\%) \\
\end{array}$ & $\begin{array}{l}80^{\circ} \\
(\%)\end{array}$ & $\begin{array}{c}\text { Paste } \\
(\%)\end{array}$ & $\begin{array}{c}\overline{\mathbf{x}} \\
(\%)\end{array}$ \\
\hline \multirow[t]{15}{*}{ Dry } & 12.06 & 0.00 & 16.21 & 18.21 & 16.81 & 20.36 & 14.32 \\
\hline & $15.43^{*}$ & 3.64 & 23.11 & 23.69 & 29.19 & 26.27 & 21.18 \\
\hline & 17.01 & 33.59 & 28.22 & 30.67 & 31.16 & 28.52 & 30.43 \\
\hline & 27.98 & 19.02 & 9.51 & 7.29 & 5.47 & 7.44 & 9.75 \\
\hline & 31.01 & 0.00 & 0.00 & 0.00 & 0.00 & 0.03 & 0.01 \\
\hline & 32.44 & 0.00 & 0.00 & 0.00 & 0.00 & 0.09 & 0.02 \\
\hline & 38.86 & 0.00 & 0.22 & 0.40 & 0.00 & 0.02 & 0.13 \\
\hline & 48.65 & 0.58 & 0.43 & 0.43 & 0.23 & 0.20 & 0.38 \\
\hline & 62.80 & 20.83 & 6.13 & 4.76 & 4.13 & 4.53 & 8.08 \\
\hline & 78.21 & 2.31 & 6.54 & 5.66 & 5.05 & 5.20 & 4.95 \\
\hline & 95.17 & 11.17 & 4.47 & 4.05 & 3.50 & 2.99 & 5.24 \\
\hline & 160.61 & 0.69 & 0.00 & 0.00 & 0.00 & 0.00 & 0.14 \\
\hline & 200.00 & 4.36 & 1.45 & 1.29 & 1.17 & 0.00 & 1.65 \\
\hline & 202.37 & 3.80 & 1.31 & 1.64 & 1.12 & 0.62 & 1.70 \\
\hline & Total (\%) & 100 & 97.61 & 98.08 & 97.83 & 96.27 & 97.96 \\
\hline \multirow[t]{12}{*}{ Rainy } & 11.86 & 6.83 & 0.40 & 0.65 & 1.51 & 26.49 & 7.18 \\
\hline & 16.51* & 0.00 & 4.61 & 3.91 & 8.03 & 12.52 & 5.81 \\
\hline & 17.57 & 15.72 & $\mathbf{3 7 . 8 3}$ & 16.28 & 15.13 & 11.79 & 19.35 \\
\hline & 26.54 & 0.00 & 14.73 & 20.62 & 16.64 & 14.56 & 13.31 \\
\hline & 37.70 & 0.00 & 0.10 & 0.14 & 0.25 & 0.36 & 0.17 \\
\hline & 47.12 & 0.00 & 0.55 & 0.58 & 0.42 & 0.73 & 0.46 \\
\hline & 57.18 & 38.01 & 15.28 & 17.37 & 16.22 & 8.44 & 19.06 \\
\hline & 73.67 & 35.49 & 10.12 & 16.06 & 14.13 & 10.19 & 17.20 \\
\hline & 89.74 & 0.81 & 7.21 & 10.27 & 9.11 & 4.73 & 6.43 \\
\hline & 191.07 & 1.08 & 1.40 & 2.10 & 3.43 & 0.87 & 1.78 \\
\hline & 220.00 & 2.07 & 2.30 & 3.33 & 5.18 & 1.02 & 2.78 \\
\hline & Total (\%) & 100 & 94.54 & 91.32 & 90.05 & 91.70 & 93.52 \\
\hline
\end{tabular}

* indicates significant differences $(\mathrm{P}<0.02)$ in the number of peptides between dry and rainy seasons.

Table 2. Percent of peptide recovery from residual whey in climatic seasons. Results in bold letters stand out the most representative values. 
protein content, while proteins of similar weights from the rainy season only represented $65.36 \%$. Unique proteins were observed in lacto-sera collected in different climatic seasons, for example, $220 \mathrm{kDa}$ in the rainy season. This fact can also be explained by the environmental factors that characterize the climatic seasons, influencing relevant aspects in livestock feeding 28 .

Even when the preparation process and the thermal treatment used could affect the recovery of specific proteins from whey, as lactoferrin ${ }^{33}$, the acid thermo-coagulation shows a good protein recovery yield from whey, that should be considered for the milk food production in general, or yet with possibilities of another application beyond food, for example, health. Thermal treatments are considered more efficient than other procedures, mainly compared to chemical treatments, as the first ones maintain the organoleptic characteristics in the product $^{34}$.

In conclusion, the results obtained in this work show that acid thermo-coagulation represents a simple, low-cost method that allows the recovery of proteins up to $82 \%$ of the original content in whey. It is remarked that the climatic season in which the whey is collected in Ecuador is not a relevant factor that significantly affects its composition, even when there were minor differences in some punctual aspects.

\section{Acknowledgment}

The authors acknowledge the University of Guayaquil's support through the Project FCI No 046-2018. Thank milk collection center "Diprolac," especially to technical responsible, Miguel Silva, to provide us with the lacto-sera samples used in this research.

\section{Bibliographic references}

1. FAO. Recursos naturales [Internet]. Organización de las Naciones Unidas para la Agricultura y la Alimentación; [cited 2019 Sep 8]. Available from: http://www.fao.org/3/am859s/am859s12.pdf

2. Pais Chanfrau, Núñez Perez MV, Lara Fiallos Marco V, Rivera Intriago LM, Trujillo Toledo Luis E, Cuaran Guerrero. Valorización del suero de leche: Una visión desde la biotecnología. Bionatura. 2017;2(4):468-76.

3. Skryplonek K. The use of acid whey for the production of yogurt-type fermented beverages. Mljekarstvo Časopis Za Unaprjeđenje Proizv Prerade Mlijeka. 2018 Mar 29;68(2):139-49.

4. Poveda E. Suero lácteo, generalidades y potencial uso como fuente de calcio de alta biodisponibilidad. Rev Chil Nutr. 2013 Dec;40(4):397-403.

5. Barać M. White cheeses as a potential source of bioactive peptides. Mljekarstvo. 201716 February;3-16.

6. Brandelli A, Daroit DJ, Corrêa APF. Whey as a source of peptides with remarkable biological activities. Food Res Int. 2015;73:14961.

7. Layman DK, Lönnerdal B, Fernstrom JD. Applications for 囚-lactalbumin in human nutrition. Nutr Rev. 20181 June;76(6):444-60.

8. Hernández-Rojas M, Vélez-Ruiz JF. Suero de leche y su aplicación en la elaboración de alimentos funcionales. Temas Sel Ing Aliment. 2014;8(2):13-22.

9. Parra Huertas RA. Lactosuero: importancia en la industria de alimentos. Rev Fac Nac Agron. 2009;62(1):4967-82.

10. Akpinar-Bayizit A, Ozcan T, Yilmaz-Ersan L. Milk-based traditional Turkish desserts. Mljekarstvo. 2009;59(4):349-55.

11. Granados-Conde C, González Cuello RE, Galindo S W, Pérez Z $D$, Pájaro-Castro N. Obtaining cream cheese supplemented with whey solids and inoculated with Lactobacillus casei. ORINOQUIA. 2016 Dec;20(2):40-6.
12. Hernández-Ledesma B, Ramos M, Gómez-Ruiz JÁ. Bioactive components of ovine and caprine cheese whey. Small Rumin Res. 2011 Nov 1;101(1):196-204.

13. Gea Kiewiet MB, van Esch BCAM, Garssen J, Faas MM, de Vos P. Partially hydrolyzed whey proteins prevent clinical symptoms in a cow's milk allergy mouse model and enhance regulatory $T$ and $B$ cell frequencies. Mol Nutr Food Res. 2017;61(11):1700340.

14. Mieles Cedeño M, Yépez Tamayo LD, Ramírez-Cárdenas L. Elaboración de una bebida utilizando subproductos de la industria láctea. Enfoque UTE. 2018 Jun;9(2):59-69.

15. Riquelme Gymesy LF. Repositorio institucional UN [Internet] [Especialización]. [Bogotá, Colombia]: Universidad Nacional de Colombia; 2010 [cited 2019 Nov 9]. Available from: http://www. bdigital.unal.edu.co/2789/

16. Pagán J, Benítez R, Ibarz A. Hidrolizados de proteína: procesos y aplicaciones. Acta Bioquímica Clínica Latinoam [Internet]. 2008 Jun 1 [cited 2019 Nov 9]; Available from: https://www.scienceopen.com/document?vid=c426 dd08-4344-4731-8280-988944336043

17. Lam RSH, Nickerson MT. The effect of $\mathrm{pH}$ and temperature pre-treatments on the physicochemical and emulsifying properties of whey protein isolate. LWT - Food Sci Technol. 20151 January:60(1):427-34.

18. Yadav JSS, Yan S, More TT, Tyagi RD, Surampalli RY. Recovery of residual soluble protein by two-step precipitation process with concomitant COD reduction from the yeast-cultivated cheese whey. Bioprocess Biosyst Eng. 20141 September;37(9):1825-37.

19. Vázquez Puente F, Villegas Arroyo G, Mosqueda Frías P. Precipitación de proteínas lactoséricas en función de la acidez, temperatura y tiempo, de suero producido en Comonfort, Guanajuato, México. Rev Venez Cienc Tecnol Aliment. 2010;1(2):157-69.

20. Martínez MJ. Impacto de la interacción entre ßlactoglobulina, caseinoglicomacropéptido y polisacáridos en coloides alimentarios [Internet] [Doctoral]. [Buenos Aires, Argentina]: Universidad de Buenos Aires; 2010 [cited 2019 Nov 9]. Available from: https:// bibliotecadigital.exactas.uba.ar/download/tesis/tesis_n4570_ Martinez.pdf

21. Cheison SC, Kulozik U. Impact of the environmental conditions and substrate pre-treatment on whey protein hydrolysis: A review. Crit Rev Food Sci Nutr. 201722 January:57(2):418-53.

22. Arce-Méndez JR, Thompson-Vicente E, Calderón-Villaplana S, Incorporación de la proteína del suero lácteo en un queso fresco. Agron Mesoam. 2016;27(1):61-71.

23. SanMartín B. Aprovechamiento de suero de quesería de origen caprino mediante la obtención de concentrados de proteinas séricas y subproductos de clarificación. Estudio de sus propiedades tecnológicas. [Internet]. [Lugo]: Santiago de Compostela; 2010 [cited 2018 Sep 15]. Available from: https://minerva.usc. es/xmlui/bitstream/handle/10347/5097/REP_209_12.pdf?sequence $=1$ \&isAllowed $=y$

24.INEN. NTE INEN 2594: Suero de leche líquido. Requisitos [Internet]. Instituto Ecuatoriano de Normalización; 2011. Available from: http://archive.org/details/ec.nte.2594.2011

25. Wang W, Vignani R, Scali M, Cresti M. A universal and rapid protocol for protein extraction from recalcitrant plant tissues for proteomic analysis. Electrophoresis. $2006 \mathrm{Jul} ; 27(13): 2782-6$.

26. Bradford MM. A rapid and sensitive method for the quantitation of microgram quantities of protein utilizing the principle of protein-dye binding. Anal Biochem. 1976;72(1-2):248-54.

27. Laemmli UK. Cleavage of structural proteins during the assembly of the head of bacteriophage T4. Nature. 1970;227(5259):680-5.

28. Kuczyńska B, Puppel K, Goł区biewski M, Metera E, Sakowski T, Stoniewski K. Differences in whey protein content between cow's milk collected in late pasture and early indoor feeding season from conventional and organic farms in Poland. J Sci Food Agric. 2012 Nov;92(14):2899-904.

29. Velázquez Vázquez C, Villa Rojas MG, Alvarez Ramírez C, ChávezServín JL, García-Gasca T, Ferriz Martínez RA, et al. Total phenolic compounds in milk from different species. Design of an extraction technique for quantification using the Folin-Ciocalteu method. Food Chem. 2015 Jun;176:480-6. 
30.Briñez WJ, Valbuena E, Castro G. Tovar A, Ruiz-Ramírez J. Algunos parámetros de composición y calidad en leche cruda de vacas doble propósito en el municipio Machiques de Perijá. Estado Zulia, Venezuela. Rev Científica. 2008;18(5):607-17.

31. Monsalve J, González D. Elaboración de un queso tipo ricotta a partir de suero lácteo y leche fluida. Rev Científica. 2005;15(6):543-50.

32. Revilla A. Tecnología de la leche. Honduras: Editorial Reverté; 1996.

33. Won HJ, Yi HC, Jung H, Cho H, Lee B, Hwang KT. Whey Preparation Methods and Thermal Treatment of Milk Affect Recovery of
Lactoferrin Using lon-Exchange Chromatography. J Food Process Preserv. 2015;39(6):1976-82.

34.Bilyk O, Slyvka N, Gutyj B, Dronyk H, Sukhorska O. Study of the different ways of proteins extraction from sheep and cow whey for "Urda" cheese production. EUREKA Life Sci. 201731 May;0(3):3-8.

Received: 19 November 2020

Accepted: 22 January 2021

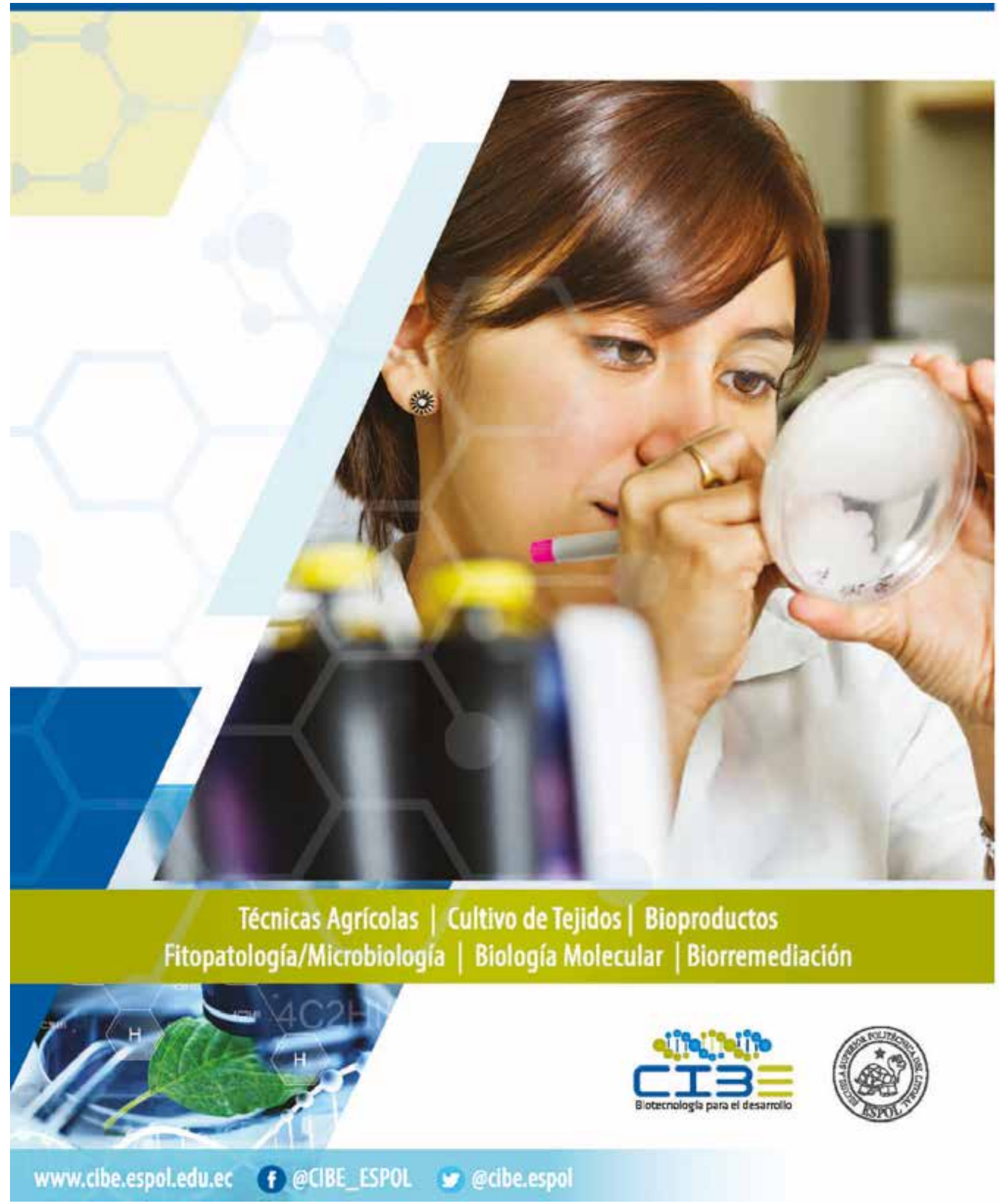

